第16回日本看護科学学会学術集会会長講演

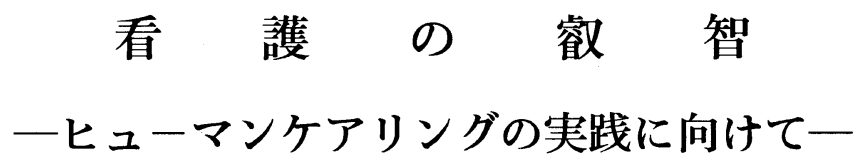

稲 岡 文 昭*1

\title{
Wisdom in Nursing
}

\author{
Fumiaki Inaoka*1 \\ *1 Japanese Red Cross of College of Nursing
}

\section{はじめに}

看護は，真空の中では存在しえずまた，発 展もありえない，看護は，医学的要因のみなら ず，常に，政治的・社会的・経済的・歴史的・ 文化的要因などによって影響を受け現在にいたっ ている. 看護に携わっている者は, 特に, リ一 ダーシップをとることが期待されている看護理 論家, 看護研究者, 看護教育者, 看護管理者は, 現状を的確に見極め, 将来の可能性を模索し， そしてその実現に向け確固たる行動をとってい く必要がある.

本講演では, 国民の健康と関連して, 現在の 社会や医療がどのような状況におかれているの か概観し，そしてその状況を克服して21世紀の 社会に向けて, 国民が少しでも人間らしく生活 でき，そして不幸にして健康障害に陥ったとき には，一人ひとりが貴ばれ厳くしまれ，少しで も質の高いケアが提供でさるように看護者はど のように貢献できるのか論じてみたいと思う.

\section{1世紀に向けての葛藤}

NHKチーフディレクターの吉田 ${ }^{1)}$ は, その 著,「21世紀は警告する」のなかで，20世紀は

“もっと速く, もっと効率よく, もっと豊かな
生活”を求めてきた「世紀の欲望」と称してい る.このような経済優先政策を取り続けてきた 結果, 世界の資源は枯渴してきており, 二酸化 炭素や放射性廃棄物などによる環境污染, 地球 の温暖化や熱帯雨林の減少などによる自然破壊, さらには海洋生態系の破壊など人間の生存を脅 かしている，にもかかわらず日本人は，“もっ と,もっと”と欲望を満たし続けているのであ る.

地球物理学者の松井によれば2), もし現在の ような生さ方をすれば，地球に人間が住めるの は短くて150年, 長くて1500年と予言している. 国際日本文化研究センター前所長の梅原 ${ }^{3)}$ は, 日本人の飽くことなき欲望について，“私には， 多くの人たちが法華経の火宅の比喻のように, 延々と燃光盛る火の中で火事とも知らずに遊び 汪らけている子供のように思われる”と述べて いる。

では私たちは, 二昔, 三昔前の窮乏生活に戻 ることがでさるだろらか. テレビ, クーラー, クルマのない生活が考兄られるだろらか. 着の み着のままひもじい思いをして暮らしていけ るだろらか. 吉田は，この点をとらえ「悪魔の 二者択一」と呼んでいる.つまり，いずれのカー ドを選んでも破局が待ち受けているのである. 
以上のよらな観点からみれば，医療も同様な 葛藤に直面していないだろらか. 20 世紀後半に おける医学知識, 医療技術, 医療機器の進歩は 驚異的である。なお，とどをる所を知らず加速 度的に進歩を続けている.にもかかわらず有病 率は上昇し続け，平成 7 年度の国民医療費も 26 兆円を越え，国民所得に対する割合も $7 \%$ と年々 増え続けている.

このような飽くなき医療の高度化の影には, 一つには脳死・臟器移植, 末期医療, 急激な人 口の高齢化など，未筸有の社会問題を生みだし， 二つには先端医療技術によって死をまぬがれ一 種の「障害者」となって生きながらえている患 者を増やし, 三つには医師の治療では治癒でき ない慢性疾患患者を激増させ, 四つには人工呼 吸器やモニター, IVHや各種カテーテル, ドレー ンなどが装着され，しかも抑制帯で拘束され非 人間化された患者を大勢生みだしてきている。 高度医療で「人間の生命」は救えたとしても, 「人の命」や「人の心」まで救えないのである. 人間の脳や心臓が生理学的に機能していても, 人間として生きていることにはならないのである.

たからといって，コンピューターで完全制御 されたオートクレーブに代わりシンメルブッシュ で消毒できるだろらか. IVHに代わり大量皮下 注射で栄養補給をすることができるだろらか. 抗生物質抜きに観血的・非観血的治療が考兄ら れるだろらか. これが吉田の指摘している「悪 魔の二者択一」なのである.

\section{葛藤解決に向けての看護の䟦知} 一ヒューマンケアリングー

吉田は，21世紀に向けて「悪魔の二者択一」 を越えた選択肢を創造する必要性を力説してい る. 梅原 ${ }^{4)}$ は, “法華経では, 菩薩がこの火の 中で遊んでいる子供たちに, 鹿の車や羊の車や 牛の車を示して火の中から救い出したとあるが, 現代における鹿の車は, いったい何なのであろ らか。私は毎日，そんなことばかり考㝋ている” と語っている.

世界的環境といら観点からみても, 保健医療 福祉といら観点からみて, 私は,「悪魔の二者 択一」を越えた選択肢は, 対象の異物を客観的
に見つけ分析し，そして診断を下し異物を除去 し治癒を目指す「自然科学の知・医学の知」で はなく, 人間の苦痛や苦悩といった主観的問題 をホリスティックにとらえ人間全体を癒すこと を目指す「看護科学の智・看護の㩚智」である

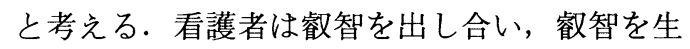
かし, 盿智を働かせ, 人間が人間らしく生き, 健康障害に直面したときには個々人間が尊ばれ 厳くしまれ治療・ケアが受けられる社会の実現 に向けて歩み出さなければならない。

国際看護婦協会の「看護婦の規律, 看護に適 用される倫理的概念」及び日本看護協会の「看 護婦の倫理規定」によっても，「人間の生命を 尊重し，また人間としての尊厳及び権利を尊重 する」と謳われている。しかし実際には患者一 人ひとりの尊厳が保障されているどころか, 患 者の多くが悲惨な状況におかれている. 薬害エ イズや末期患者の医師による安楽死が大きな社 会問題となっているが，看護者は問題が起きる までどのようなケアを行っていたのだろらか.

国際看護婦協会及び日本看護協会の倫理規定 に嵒われているのみならず, 多くの看護関係書 にも, 看護の対象者に心から関心を示し, 対等 な立場で積極的に傾㯖し, 共感的に理解し, 対 象者の苦痛や苦悩を和らげ，そして安らぎや希 望を与えるのが看護者の役割であると記述され ている、しかしながら, 看護の対象個々を貴び 戦くしみ, もっとも深い意味で, その人が成長 することに手を貸し，その過程で看護者も成長 するという，いわゆるメイヤロフらがケケアの 本質」で描写している意味のヒューマンケアリ ングを“なぜ”行らことがでさないのだろらか. お互いにケアする心をもち，お互いを「ささえ あら」心を大切にするといら真の意味のヒュー マンケアリングを“なぜ”実践することができ ないのだろらか．前述したように，わが国では なによりも効率性や経済性, 合理性や即効性が 最優先されている.これらの価值観にのっとっ て政治や経済, 医療制度が仕組まれ，そのよう に人的資源も配置され, 医療従事者の倫理感に も多大に影響を与えている. 残念ながらヒュー マンケアリングはこれらと対局にある概念であ る.この点に目を留めただけでも，真の意味の 
ヒューマンケアリングの実践がいかに困難であ るか理解できよう.

ヒューマンケアリングの実践には, これら数 多くの要因が複雑微妙に関与していると考兄ら れるが，私は，なにより看護者自身が人間を尊 び心より厳くしむというヒューマンケアリング のもつ真の意味とその価值について十分に理解 していないからではないかと考光る。たと理 解が得られていたとしても，それは知的・概念 的であって決して行動的・実践的レベルではな いように思う。

\section{ヒューマンケアリングの真の意味と価値の認識}

国際日本文化センターの森岡6) は, “今まで は，自分のことは自分で決定し対処でさるよう な理性と良識を供えた「近代的個人」が社会秩 序を形成することで近代市民社会は成立するも のだと考えられてきたが，医療技術が限りなく 発展しづづける日本では, 自分のことは自分で 決定し処理できない患者や障害者, 痴呆や寝た きり老人は増えつづけ，21世紀に入ると，「近 代的個人」の数をらわまわって，他人からの支 えをらけてはじめて生きてゆけるような人たち が社会のマショョリィになる可能性がある”と 述べている，つまり，自分のことは自分で決定 し対処できるといら考方では21世紀の市民社 会は成立せず，お互いに貴び敩くしみ，お互い に「ささえ」，「ささえあい」ながら，お互い に成長を図っていくという真のヒューマンケア リングが重大な意味と価值をもってくるのである.

医療機関や医療施設であっても, 主観的・個 人的条件をできるだけ排除し, 客観的, 分析的, 科学的, 心身二元論でとらえようする超近代医 学がすべてではなく, 苦痛や苦悩, 不安や無力 感など患者の主観的な問題をホリスティックに とらえ, そして病理学的データと統合し, 柔軟 的・創造的にアプローチするというヒューマン ケアリングの大切さが少しづつではあるが認識 されはじめてきている．柳田 ${ }^{7,8)}$ は, “現代医 療の進歩は, 命を臟器とか遺伝子とかに小さく 区切り, 細分化してしまい, 人間全体を見なく してしまらマイナスがある，大事なのは人間性 の見直しと復権である”と主張している. 実際,
多くの看護者は，患者が分断され，分断された 部分のみが各専門医によって治療されているの を目のあたりにし，誰が患者全体の治療に責任 をもつのか危惧の念をもっている.

看護の対象である患者の多くは, 食事や排泄, 保清など身のまわりについて自己管理すること ができない状態におかれ，生活感覚も含め「生 活から蹯外」されている. また対象の喪失や限 られた対人接触, 感覚剥奪や社会的役割の喪失 などに見舞われ，現実の「人間関係から疎外」 されている，さらに死の恐怖や怯え，苦痛・苦 悩を伴ら治療や処置，ボディーイメージを損傷 する手術などにより，「生から蹯外」されてい る.このような状況は人間に堪え難い苦痛や苦 悩, 激しい不安や恐怖, さらには死娘どの孤 独感など人間の否定的といえる感情を喚起させ る.これらは患者からみれば主観的な問題であ り，看護者からみれば全人的な問題と言える. 土屋 ${ }^{9)}$ はこのよらな状態におかれた患者のこと について，“たまらない不安や孤独に苛まれ， 搔き乱され，忍びよってくる死の恐怖に怯光， 独りでベッドに横たわっていることと，自分に 寄り添ってくれ，自分のことを思ってくれ，共 感してくれ，信頼してくれる人と心拈きなく分 かち合えることとは天国と地獄ほどの差が存在 する”と描写している，彼らによりそい，日常 生活を助け, 人間の深い内的世界を洞察し, 不 安や恐怖, 苦痛や苦悩を共有し，そして少しで も安らかに過ごすことができるようケアするこ と，これはまさに看護の心である，さらに潜在 的治癒力を喚起し, 彼ら自身が自分の置かれて いる䈌しい状態を受け入れ，乗り越え，そして 自己成長が図れるように「ささえる」というこ と, これはまさに真の意味のヒューマンケアリ ングである.

個々患者が心から貴ばれ厳くしまれ治療やケ アが受けられるためには，患者自身が医療の場 に参加し, 決定に参与することが重要である. これには，憲法で保障された基本的人権を守る ためにも不可欠と言われるインフォームド・コ ンセントが前提となる，看護者にとって重要な ことは, 医師の行ったインフォームド・コンセ ントを患者や家族に理解しやすいように説明し 
な拈すことではなく，患者が心抒きなく自己決 定ができるよう配慮することである，斎藤 10$)$

は，普通，心身ともに弱った患者は一人っきり で自己決定をするのではない，周囲の状況を慮 り，自分の立場を諮りながら，しかも決定の結 果, 周囲の人たちが自分をどのように思らかを 考慮し，周りとの関係を慮って態度を決定する と述べている，つまり，患者が安心して自己決 定できるには，患者が心やすらかでいられるよ らな, 自分らしさが尊重されるような日頃から の看護者の患者への温かく配慮する心が前提と なる。

21世紀の社会は，このように看護の力が期待 され，問われている.看護者は，まず，真のヒュー マンケアリングの意味と価值について，あらた めて十分に認識する必要がある.

\section{真の意味のヒューマンケアリングの概念}

ケア/ケアリングの基本的概念はなにも目新 しいものではなく, 古来から, 健全な親子の関 係にみられる。ローレンッツの発見した“刷り 达及現象”のように11)，母親は子どもに拈乳 をらくませることによって一生消光ぬ母性本能 に火をともすと山本は母乳の必要性を主張して いる ${ }^{12)}$.母親はこの母性本能をもとに，子ぞ もに慈しみの心をもって授乳, 排泄, 清潔など, 日常生活のお世話をし，そして子どもをはぐく み育てる. 同時に，母親は子ぞもよりはぐくま れ育てられる．ここには「ささえ」「ささえら れる」，すなわち「ささえあら」といら相互関 係が存在する，この関係をとおして，母親は子 どもの痛みをわが痛みとして感じ，その痛みを 和らげるために自己投入する. やがて母親は個々 子どもの個性をみいだし，その個性を大切に育 てる.

この健全な親子の関係でみられる「ささえあ ら」といら概念は, 私は, 看護者と看護の対象 との関係にも基本的に適応できるのではないか と考える.看護者は対象に「ものや情報」, 「技術や技能」，さらには「心の糧や存在」を 与え，「ささえる」というヒューマンケアリン グは，一見，一方交通のように思われるが，実 は, 看護者は, 対象との相互作用のなかで生き
ている.看護といら役割をもった人と健康障害 をきたした人との間には意味ある関係が存在し ている. 病院においては, 手術直後の患者や重 症患者, 重度の心身障害者や未熟児, 痴呆老人 や植物様状態にある患者は, 多くの人々の「さ さえ」を必要とし，「ささえ」は一方的のよう に思われる、しかし，実は，両者が必ず「ささ え」,「ささえあって」いるのである. 看護者 はこれらの患者のケアを介して自分を知ること があり，また患者にちょっと頭をさげてみたい 気持にさせられることがある，患者から「ささ 光られているよい証拠である. 真の意味のヒュー マンケアリングには, このような学習の機会や 患者への感謝の気持を大切にすることが必要不 可欠である.

倫理学者の土屋 ${ }^{13)}$ は, 患者との「ささえあ ら」関係の根底にある原則について次の 3 つを 挙げ説明している. 第 1 には, 相手の心を理解 し，尊重してかかわっていこうとする気持であ る、時間を惜しまずに，共にそばにいるという ことこそがかかわりの本質である，実際には， 自分の時間をさいて側にいてくれるという信頼 感・安心感が，かたくなな患者の心を融かして コミュニケーションを可能にするのである. 第 2 には, 患者の能力を信じるということである. 患者が危機状態から脱したり，悲嘆のどんぞこ から立ち直ったり回復したりする能力, 判断や 同意ができるようになるといら潜在的能力, さ らには成熟した人間になって成長するといら可 能性である、第 3 には，事実に直面しそれを受 ケ容れなければならないのは患者であって, 誰 でもないということである.看護者は患者の苦 しみや死の恐怖を自分自身の経験に照らし合わ せ共感することができるが, 看護者が決して代 わってやることができないのである. 事実を直 面し，そして受け止めなければならないのは患 者本人なのである.このためには, 前述したよ らに，患者に情報の公開と説明，そして患者の 自己決定が重要なのである.

親が子どもの個性を見いだし，その個性を尊 重しはぐくみ育てていくのと同様に, ヒューマ ンケアリングにかかわる看護者は, 可能なかぎ り患者の個性を尊重することが大切である．な 
ぜなら患者が安心して自己決定を下すことがで きるには，先ず，一人ひとりの患者の「その人 らしさ」が尊重される必要があるからである. その患者によって生き方や考方方, 価値観や信 条などがそれぞれ異なっている，具体的にどの ようにケアすればよいか，何をすれば患者の瘉 しにつながるのかなどといら点も，きわめて多 元的である. とすると望ましい基準は患者自身 にあり, 医療従事者ではないことは明白である. その人のありのままの姿を見つめ, 認め, そし て価值観を尊重することなしに，患者を「ささ える」ことはできないのである.

このように，看護者と患者の間の「ささえあ ら」関係とは, 患者の重荷を代わりに背負らこ とではなく, 食事介助, 清拭, 排泄介助などの 身体的なケアを行いながらも，心を「ささえる」 ということ, つまり, 重荷を背負っている患者 を精神的に独りぼっちにしないといらことであ る. ここに看護者が行ら真の意味のヒューマン ケアリングの精神が生きてくるのである.

\section{真の意味のヒューマンケアリングの 実践に向けて看護学教育}

看護の現場において，一人ひとりの患者を貴 び繁しみの心をもってケアするといら真の意味 のヒューマンケアリングを浸透させていくには, ヒューマンケアリングの意味と価值の認識, 概 念の理解だけでは不十分である.看護教育や臨 床看護現場において，「刷り达み現象」のよう に，あるいは「母乳を介しての母性本能の喚起」 のように, 看護学生が一生ヒューマンケアリン グの実践を可能にする，ヒューマンケアリング の「面白さ」や「楽しさ」,「手応え」, さら にはヒューマンケアリングの「神髄」を身をもっ て体験するすることが必要不可欠である.

看護学を教授・研究する 4 年制大学のなかに は，医師によって看護学が教授されているとい ら現状がある. また看護領域の研究でありなが ら，医師の教授によって指導されているといら 現状もある.さらに看護短期大学のなかには, 看護の免許をもった教授よりも医師の免許をもっ た教授が多いといら現状もある。確かに，現在 は看護婦教育から看護学教育の移行期である.
また看護学は医学と最も隣接領域の学問である. このような前提を受け入れたとしても，看護学 教育は他の学問領域に比べ余りにも医学志向に 偏っている. 長年, 学問的基盤を客観的, 分析 的，心身二元的な考方方に依拠してきた教授か らの指導は，ヒューマンケアリングという概念 から対局にある自然科学的な発想を基盤とする であろう，21世紀の保健・医療・福祉社会は， 前述したように，キュアよりもケアリングでの 癒しを必要とする人々が激増することが予想さ れる.看護学が実践の学問とするなら, 看護学 は一人ひとりの患者が貴ばれ心より撖くしまれ る真の意味のヒューマンケアリングに生かすこ とがでさるような学問でなければ無意味である.

ヒューマンケアリングの実践といら観点から みると, 現在の看護学教育の第 2 の問題点は, 看護学教育に携わっている看護教員自身の問題 である・ヒューマンケアリングの実践には, 「主体性」や「判断力」,「創造的な発想」や 「柔軟的なアプローチ」が必要とされる．看護 教員は，確かに，これらの重要性については言 及しているが，実際には，知識を詰め込久記憶 させるといら教育に偏重しているきらいがある. また，「チームナシング」や「看護過程」，「プ リマリーナーシング」や「看護診断」に象徵さ れるように，外国の理論や概念について十分に 論議が尽くされないまま教育や臨床で用いられ ている. 問題の所在を明らかにしたり, 問題を 解決したりするときの手がかりにメリットはあ るが，そこにかかわる人間の微妙な心情や生活 習慣, 矛盾を抱えた人間像が見えにくくなると いらデメリットが存在する.さらに，看護専門 学校のなかには, 原理・原則よりも手順やマニュ アル，あるいは技術に過剩に依拠した「マクド ナルド方式」の教育が行われている. 元上野動 物園の中川園長は朝日新聞で次のように語って いる14).

“6 年生の夏休み, 生まれて初めて上野動物 園に行き，あこがれの動物が生きているのを見 て, 本当にびっくりした. しかも, 後ろの方に, その動物を飼育しているやつがいる. 日本にこ んなところがあるのか，オレはここに来たい， と強く思いました。それから園長に手紙を何度 
か書いたりして，1952年，上野動物園の見習い になりました．最初に師事したのが「鶴の師匠」 とも言われた高橋峰吉さんでした. 高橋さんが 掃除すると，鶴が自分でよけていく，掃除の跡 の模様の波間に, 鶴が浮かんでいるように見え る. 名人芸でした． 1 カ月くらいたって「やっ てみろ」と言われ，私がゲージに入った。とた んに鶴がばたついた．静めようとすればするほ ぞ細かな毛が散乱し，掃除どころじゃない。 「今まで何を見てたんだ。オレの手順をみるん じゃない，鶴を見るんだ」と言われ，もら一度 見ていたら，鶴がよけていたんじゃなくて，高 橋さんが鶴のリズムで歩いていた．そのとき， 仕事を覚えるとは，手順を覚えマニュアル通り 過不足なくやるといらことではない，特に飼育 は，百パーセント相手に合わせることができな ければ成り立たないのだと知りました.”

中川園長のこの言葉は, 看護者の患者へのケ アに際しても同様のことが言えるのではないだ ろらか. 既習の理論や知識, マニュアルにそっ て患者をケアするのではなく，一人ひとりの患 者を見て，その人らしさのリズムに合わせ既習 の理論や知識を生かしていくのが，ヒューマン ケアリングである. Reed ${ }^{15)}$ は，米国の最近の 看護界の動向をとらえ, 臨床における看護ケア の実践そのものは，知識や概念の構築そのもの であるという認識の高まりについて述べている.

法隆寺や薬師寺の金堂の復興をはかった, 最 後の宮大工といわれる西岡 ${ }^{16)}$ は，“技術という ものは, 腕だけ, 手先だげの器用さだけでなく, あとのことを考える心遣い，そして培われてき た勘や感覚に支えられているでしゃろな. 技は 技だけで身につくもんやない，技は心と一緒に 進歩していくんです.一体ですなあ”と.ヒュー マンケアリングの実践に向け, 一考も二考も要 する味わいある言葉を残している.

現在の看護学教育の第 3 の問題点は, 歴史の 浅い看護学は他の学問領域に追いつかざるを得 ない状況にあるためか，余りにも概念や理論を 重視し, 臨地・臨床実習といら実学を軽視する 傾向にある. 厚生省の保健婦助産婦看護婦養成 指定規則以上の時間数, 臨地・臨床実習を行っ ている学校は皆無に近いといら事実からも推し
量ることができる．最終学年の臨地・臨床実習 であっても，一人の受持患者のアセスメントや 看護診断にこだわり，あるいは膨大な実習記録 のため情報収集に終始し，ベッドサイドで患者 に寄り添い，共に過ごし，「ささえあう」時間 が少ない，後述するように，個々患者は，同じ 診断名であっても千差万別な状沉に扔かれてい る.臨床に抢ける実習は, あらかじめアセスメ ントして患者にかかわるのではなく，患者とか かわりながらアセスメントし，アセスメントし ながらかかわり支えるといらことが重要になっ てくるななより患者は一刻でも早く，激しい 苦痛や苦悩, 不安や怯えを癒してもらうことを 望んでいるのである. 患者に寄り添い, 患者と 共にいて，共に苦しみ，共に笑い，共に喜ぶこ とを通して，真のヒューマンケアリングの神䯣 にふれることができるのである.

西岡 ${ }^{17)}$ は, “職人がいて建物を建て，それを 学者が研究しているんですから, 先に私らがあ るんです，学者が先におったんやないんです. 職人が先に抒ったんです.”“学者にしてもどれ だけ深い学問をしているかということですな. 学者という人たちは本はようけ読みますやろけ ぞ，なかなか実際のことは知りませんやろ。そ れでいて自分の学説にとらわれてますな.これ がいかんのですよ.”と述べ, 実学の重要性を 暗示している.

私が，看護学生の実習を重んじる第 3 の理由 は，ヒューマンケアリングにはなにより実践的 判断能力が関係するからである.たと学生で あっても受持患者にケアしているかぎり，ケア に関する実践的判断を絶え間なく行っていかな ければならない，現在の患者の状態について判 断するには，単に，学習してきた専門的知識や 技術のみでなく, 感覚や知覚による判断が必要 である.この感覚や知覚による判断にはそれま での経験がものをいう．さらに患者は刻々と微 妙に, しかも多様に反応するため, 患者の変化 を的確にとらえ瞬時に判断する能力が問われる. 最終的には, これら一連の判断を統合する能力 が問われる.このような実践的判断は，ペーパー ペイシャントの分析や偽装患者とのロールプレ イでは限界がある。さまざまな状況下でさまざ 
まな患者との相互作用を経験しないかぎり， 「いま，ここで私は何をすべきか」といら主体 的かつ的確な実践的判断能力を身につけること ができない，私は，理論と実践との統合を目的 とする臨床・臨地実習を看護学教育のなかでもっ と重視しないかぎり，ローレンッツの発見した 「刷り込久現象」や「母乳をとおしての母性本 能の哃起」のように, 学生に真の意味のヒュー マンケアリングの本質について “インプリンティ ング”することができないと考える.

最後にもら一つ看護学生の臨地・臨床実習に 私がこだわる理由は, 実習をとおして学生の個 性が明確になり, 指導教員は個々学生の個性を 生かす機会となるからである，自分の個性が生 かされた体験をもつ者が，他者の個性やその人 らしさを慮ったケアを行らことができると考光 るからである。西岡 ${ }^{18)}$ は, “個性を大事にする 時代になったといいますが，みんな規格品には まった同じもののなかで暮らしているようにし かみえません，人を育てる育て方も，みんなが 同じになっているんじゃないかと思っています.

私らが相手にする桧は人間と同じで, 一本ずつ が全部ちがらんです。たった一本の木でも，そ れがどんな風にして種が蒔かれ, 時期が来て, 仲間と競争して大きくなったんやろか。そこは ぞんな山やったんやろ, 風が強かったんやろか, お日さんはどっちから当ったんやろ，私らはそ んなことを考えながら，見たり，触ったり，旬 いをかいで，それぞれの木の癖を見抜いて，そ れにあった使い方をします，そうすれば千年の 樹齢の桧であれば，千年以上もつ建造物ができ るんです. 法隆寺がそれを証明しています。” と，手間ひまをかけ，そして個性を生かす教育 の重要性を指摘している.

わが国では, 明治初期より欧米諸国に追いつ き，追い越すことを目指し，がむしゃらに西洋 文明や自然科学を取り入れてきた歴史がある.

現在, 多くの学者はそのつけがまわってきた事 実を認めている. 看護学教育も同様に, 他の学 問領域に追いつき，追い越すことを目指し，余 りにも知識や技術, 概念や理論を強調するきら いがある.ここであらためて人間の尊厳を優先 するヒューマンケアリングの実践に向けて, 看
護学実習を含めた看護学教育について問い直す 必要がある。

\section{真の意味のヒューマンケアリングの 実践に向けての臨床看護現場}

臨床で看護の対象を貴び心から厳くしむヒュー マンケアリングの実現には，先ず，どのような 職場環境で働いているか，それが患者にとって どのような意味があるか十分に認識することで ある. 臨床では, 医師の権限は絶対的であり, 患者の生命を救らことに絶対的な価值が招かれ ている．このため看護者・患者とも医師の指示 を遵守し，医師の診療・処置を何よりも優先し なければならない，医学モデルが優先されてい る環境は，患者の個別性やその人らしさを慮ば かったケアよりも，てきばきと医師の診療・処 置の介助を行い，かつ看護業務を効率よくこな すことに価值がおかれる．また患者の心理社会 的要因よりも, 病理学的知識や薬理学的知識が 求められる。しかしがら医学モデルは重症患 者や救命救急患者であれ，慢性疾患患者であれ， 中川19,20) は, 次のように鋭く現代医学の限界 を指摘している。人間はさまざすな環境のなか で生活しているが, 一旦, 病気と診断され入院 生活を余儀なくされると, 疾患以外のものはす ベて排除され，身体の一部の異常のみが治療の 対象となる. 特に重症患者や救急患者の場合に は顕著である，そこには，患者一人ひとりの個 性やその人らしさが考慮されたり，人間の尊厳 について論じられたりすることはない，自然科 学の目をとおしてみつめた「生命」であり， 「いのち」の大きさやその意味の重大性につい て問われることはない，そのよい例が医師が下 す診断名である。例光ば胃癌と診断がつけられ ると, 生物学的にいっても多くの種類があり, 経過もさまざまであり，まして疾患に影響を与 える心理社会的要因もさまざまである．医学的 診断名はそれらを一切放棄させ画一化させてし まう㗢きをもっていると.

医学モデルが優先されている職場では，たと え患者自身の自己管理が問われる慢性疾患患者 のケアに際しても同様な問題がみられる. 慢性 病患者の病気のプロセスをみると, 素因といら 
生物学的因子のほかに，生活習慣やライフスタ イル，さらにストレスや社会的サポートといら 要因が関与している.これらの要因間のバラン スが崩れると，「頭痛」や「肩凝り」，「腰痛」 や「風邪」，その他「下痢」など，いわゆる 「身体の調子が悪い」といら病的体験をする。 休養したり，気のせいにしたり，否定したり， あるいは民間療法を取り入れてみたりして，な んとかして元の状態復しようとする.しかし 何をしても良くならず段々と悪くなってくると 病院を訪れることになる。そして前述したよう に診断名がつけられる. 生活習慣病と称世られ ていることを承知しながらも，診断名がつけら れると患者のケアや指導に際しても病名や病理 が重視される.これは, 臨床の看護者が看護学 生のことについて，“受持患者の心理社会的な 背景はよく把握しているが, 病気のことは勉強 していない”といら指摘に象徵される.

以上説明してきたように医学モデルが優先さ れている職場環境で，しかも多忙な業務に追わ れている看護者が, 個々の患者の主体性や主観 性を重んじる真の意味のヒューマンケアリング を実践することは，いかに困難なことであるか 理解できる。

しかしながら医学モデルではなく, 看護モデ ルによって患者を少しでも安楽に, 少しでもよ りよい状況に，少しでも自己成長が図れるよう にとコッコッとベッドサイドでケアしている看 護者もいる．医師が慢性疾患患者を治癒できな い理由の一つは, 身体の一部の器質的な異常で はなく, 人間の身体的・心理的・社会的なト一 タルな機能の障害であることである．「症状」 はその全体の機能障害を示す一つの赤信号なの である、そのためその「症状」のみを対象に治 療しても，当然治瘾にはいたらないのである. 医師の役割と異なり, 慢性疾患患者を全人的に 捉らえる必要性を認識している看護者は, 患者 自身がそのことに気づき，それがどらいう意味 をもっているかを学習できるようにホリステイッ クにかかわっている. 患者自身がそのメカニズ ムを理解しなければ根本的解決を図れないので ある. 慢性疾患患者にその理解を助けるのが真 の意味のヒューマンケアリングである.そうす
ると看護者は医学的知識や薬学的知識以上に, 人間学的・行動科学的知識と共にそれをケアに 生かす技に巧けていなければならないのである.

エキスパートと言われる看護者は，たとえば， 医学的データが相変わらず悪く, 特に変化がみ られない状態であっても, 患者の死期を直観か のように予測したり, あるいは鼻腔栄養から口 腔栄養に切り替える際の判断をあたかも直観か のように行っているが，いずれも的確な判断で あったケースがよく報告されている，一見, 直 観的判断は「科学的判断」とは言われず, 合理 的・学問的ではないと軽視される傾向がある.

しかしながら，的確な直観的判断ができる看護 者は，日頃から患者一人ひとりに貴び厳くしむ 心をもってケアし，患者の全身状態を注意深く 観察している．そのため患者の少しの変化でも 一瞬のらち捉らえることができるのである．こ のようにして患者の全身状態を一瞬のらちに的 確に判断できる能力が培われるのである. 実際, 米国における直観的判断に関する研究 21 23) で は，的確な直観的判断に優れている看護者は， 患者との直接的接触, 患者に対する密接な関係 感情, 熟達した技術, 患者との関係で生じたパ ターンや類似性の認知, 概要の理解と柔軟的発 想, 卓越した感覚, 自己確信などに優れている と報告されている。つまり，直観的判断に優れ ている看護者は, 真の意味のヒューマンケアリ ングを確固たる看護観にすえ, 専門職としての 自立精神をもち，そして逞しい行動力を有し， そしてなによりクリニカル・センスないしクリ ニカル・スキルといわれる卓越した感覚に富ん でいるのである. 当事者はそれをあえてヒュー マンケアリングと呼んでいないかもしれない。 またそれをあえて言葉で明確に表現していない かもしれない，さらにその有効性をあえて数字 で実証していないかもしれない，しかし今まで 述べた真の意味のヒューマンケアリングの実践 を行ってきているのである。

\section{真の意味のヒューマンケアリングの 実践に向けての看護指導者の役割}

21世紀の社会において，「悪魔の二者択一」 を越えた選択肢がヒューマンケアリングであり， 
看護学の本質であるとしたら, 真の意味のヒュー マンケアリングを実践していくには，看護管理 者や看護実践者のみでなく，看護理論家や看護 研究者, 看護教育者の指導者は, 㩚智を出し合

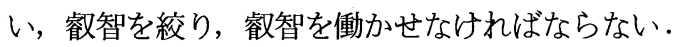

確かに，米国ではワトソン ${ }^{24)}$ やレイニンガー25) 等の看護理論家が「ヒューマンケア」や「ヒュー マンケアリング」について理論化している. し かしわが国の文化や生活習慣に密着した独自の ヒューマンケアリングの概念や理論について構 築していく必要があるように思う。私が述べて きた「真の意味のヒューマンケアリング」と彼 らが論じているものとは同じではない，看護理 論家や研究者は, 看護実践者と協働し, 「看護 に括けるヒューマンケアリングとは」,「ヒュー マンケアリングの構成要素とは」,「ホリスティッ クとは」「全人的とは」「癒すとは」など，わが 国独自の，かつ看護独自の言葉で論理的に説明 する仕事に取り組んでいかなければならない。 わが国に括いて看護者が頻繁に用いている「治 療的対人関係」や「看護過程」,「看護診断」 や「看護治療学」などは, 看護独自の用語では なく, 自然科学や医学の領域で用いられている 専門用語である. 看護学が医学や他の学問と異 なり, 独立した学問であるといらことをアピー ルするためにも, 看護の現象を看護独自の言語 を用いて，しかも他者が容易に理解できるよう 説明する必要がある.ヒューマンケアリングの 有効性についても, 自然科学の方法論でなく, 人間科学や行動科学の方法論を用いて実証して いく必要がある.わが国における 4 年制看護系 大学はあと数年で100校を越え, 大学院も 2 桁 になることは時間の問題と言われている．看護 と名のつく学会も 30 余を越光, 年間 1 千件をは るかに凌ぐ研究論文が発表されている.看護学 が実践の学問とするなら，一人ひとりの患者が 貴ばれ心より緟くしまれ真の意味のヒューマン ケアリングに生かすことができるような学問で なければならない、私は，基礎研究や基礎学問 を否定するものではないが, 看護の領域に関す るかぎり, 研究のための研究であったり, 学問 のための学問であってはならないと考える.

\section{おわりに}

昨今の厚生省の医療政策の動きをみると， すます効率化・合理化といらことが最優先され ている．患者一人ひとりを貴び敩くしむという ヒューマンケアリングは, 周囲のあらゆる要素 が能率化・合理化が図られたあとでも, 最後ま で人間の手で目で行わなければならないもので ある. 一方, 今日の医療問題は, 脳死や臓器移 植, 老人医療の問題に象徵されるように, 近代 科学社会における「人間の生き方」そのものが 問われている，このような状況のなかで, 看護 者はどのような役割をとっていくか，21世紀の 社会に向けて重要なことである.

平成 7 年元旦の朝日新聞の社説に, “近代文 明あるいは近代の「知」は，親を山に捨てる悲 劇は消えた、だが，生産に役立たないものを厄 介視する思想は根強く残った。……健常者本位 の考学が強まり，それ以外は排除しようとする 精神的「らば捨て山現象」は消えていない. 21 世紀に向け，新しい「知」を育てる必要がある.” と提案している、私は，「看護の瑴智」こそ待 ち望まれた，新しい「知」であることを願って いる. 最後に, MASSACHUSETTUS GENERAL HOSPITAL の看護部の理念を紹介する.

We believe that the essence of nursing practice is caring

caring which is a sience and an art is deliverable teachable $\&$ researchable is accompanied with wisdom knowledge compassion \& competence

\section{文献}

1 ) 吉田直哉：21世紀は警告する，「悪魔の二 者択一」を越えて, 日本放送出版協会, pp.16-61, 1989

2 ) 松井孝典：地球・宇宙そして人間, 德間書 店, 1990 
3 ）梅原猛: 共生と循環の哲学, 永遠を生さる, 小学館, pp.45-90, 1996

4 ) 梅原猛: 論点, 地球環境守るには文明生活 の転換を, 朝日新聞, 1991

5 ) M.メイヤロフ, 田村真・向野宣之訳 : ケ アの本質, ゆみる出版, 1987

6 ) 森岡正博：方法としての「ささえあい」 (森岡正博編),「ささえあい」の人間学, 法蔵館, pp.15-22, 1994

7 ) 柳田邦男：ことば抄，朝日新聞，1995

8 ）柳田邦男：犠牲，文藝春秋，pp.197-234, 1995

9 ）土屋貫志：分かちあいとしてのささえあい (森岡正博編集),「ささえあい」の人間学, 法蔵館, pp.304-314, 1994

10）斎藤有紀子：自己決定をささえる（森岡正 博編), 「ささえあい」の人間学, 法蔵館, pp.25-39, 1994

11）K. ローレンツ, 日高敏隆訳：ソロモンの 指環, 動物行動学入門, 早川書房, 1986

12) 山本高治郎：母乳, 岩波新書, 1983

13）土屋貫志：「ささえる」とはどらいうこと か(森岡正博編),「ささ它あい」の人間学, 法蔵館, pp.47-63, 1994

14）中川一郎: 私と先生, 朝日新聞, 1991

15) Reed, P.G.: Transforming Practice Knowledge into Nursing knowledge-A Revisionist Analysis of Peplau, IMAGE, 28 (1) , 29-33,
1996

16）西岡常一：木のいのち，木のこころ, 草思 社, pp.18, 1995

17）西岡常一：木のいのち，木のこころ，草思 社, pp.73-75, 1995

18）西岡常一：木のいのち，木のこころ, 草思 社, pp.68-69, 1995

19）中川米造・小林昌廣：「医の知」の対話, 人文書院, 1995

20）中川米造：医療のクリニック，〈癒しの医 療 $>$, 新曜社, 1994

21) Schraeder, B.D. : Using Intuitive Knowledge in the Neonatal Intensive Care Unit, Holistic Nurse Practice, 1 (3) , 45-51, 1987

22) Young, C.E.: Intuition and Nursing Process, Holistic Nurse Practice, 1 (3) , 52-67, 1987

23) Benner, P.D. \& C.Tanner: Clinical Judgement: How Expert Nurse Use Intuition, American Journal of Nursing, January, pp.23-31, 1987

24）J. ワトソン, 稲岡文昭・稲岡光子訳：ワ トソン看護論, 人間科学とヒューマンケア, 医学書院, 1992

25）M.レイニンガー, 稲岡文昭監訳 : レイニ ンガー看護論, 文化ケアの多様性と普遍性, 医学書院, 1995 